\title{
Kutse- ja kõrgkoolides õppijate autonoomne motivatsioon ettevõtlusega alustamisel ning selle seosed enesejuhtimise, algatusvõime ja loovusega
}

\author{
Elina Malleus $^{\mathrm{acl}}$, Urve Venesaar ${ }^{\mathrm{b}}$, Kaja Mädamürk ${ }^{\mathrm{ab}}$, Grete Arro ${ }^{\mathrm{c}}$ \\ ${ }^{a}$ Tallinna Ülikooli loodus- ja terviseteaduste instituut \\ ${ }^{b}$ Tallinna Tehnikaülikooli ärikorralduse instituut \\ ${ }^{c}$ Tallinna Ülikooli haridusteaduste instituut
}

\begin{abstract}
Annotatsioon
Ettevõtluse kontekstis on oluline uurida, mis motiividel alustavad ettevõtjad tegutsemist ning kuidas need mõjutavad edasist ettevõtlusprotsessi. Motiivide uurimine seotuna teiste ettevõtluses oluliste pädevustega (nt enesejuhtimine, algatusvõime ja loovus) võimaldab paremini mõista motivatsiooni olemust ning pöörata kõnealustele teemadele tähelepanu juba ettevõtlusõppes. Uurimusega soovitakse rakendada eri valdkondades (nt haridus, psühholoogia, tervishoid) levinud isemääramisteooriat ettevõtlusõppes. Selleks uuritakse 497 kutse- ja kõrgkoolide õppija kogemust ning motiive ettevõtlusega alustamisel, lähtudes autonoomse ja kontrollitud motivatsiooni teooriast ning sidudes valitud teoreetilise lähtekoha varem ettevõtluse kontekstis esile tõstetud pädevustega. Uurimistulemusena ilmneb, et õppijad, kes lähtuvad ettevõtlusega alustamisel pigem autonoomsele motivatsioonile viitavatest põhjustest, annavad kõrgemaid hinnanguid oma enesejuhtimisoskuste, algatusvõime ja loovuse kohta. Seega võib autonoomse motivatsiooni teadlik toetamine ettevõtlushariduses olla seotud ka õppijate edasise parema toimetulekuga ettevõtlusmaastikul.
\end{abstract}

Võtmesõnad: ettevõtlusõpe, autonoomne motivatsioon, ettevõtlusega alustamise motiivid, enesejuhtimine, algatusvõime, loovus

Loodus- ja terviseteaduste instituut, Tallinna Ülikool, Narva mnt 29, 10120 Tallinn; elina.malleus@tlu.ee 


\section{Sissejuhatus}

Ettevõtluses on tähtis teadvustada ja terviklikult toetada ettevõtluspädevuse, sh teadmiste, motivatsiooni, oskuste, hoiakute ja uskumuste arengut, mis tagaks edu, vastupidavuse ning võimaldaks hakkama saada pidevalt muutuvas maailmas. Artiklis võetakse fookusse motivatsioon, mis on ettevõtluses olnud oluline uurimisobjekt, sest see võimaldab mõista, mis kannustab inimesi tegelema ettevõtlusega ning kuidas mõjutavad ettevõtlusega alustamise motiivid ettevõtte edasist käekäiku (vt Aijzen, 1991; Carsrud \& Brännback, 2011; Shane, 2003). Siinses uurimuses eristatakse autonoomset ja kontrollitud motivatsiooni (nt Ryan \& Deci, 2000, 2017), mida ei ole ettevõtlushariduse valdkonnas kuigi palju uuritud.

Ettevõtjad ja ettevõtlikud töötajad ei erine mitte ainult enda motivatsiooni tugevuse aspektides, vaid ka selle kvaliteedis (Carsrud, Brännback, Elfving, \& Brandt, 2009; Gagné \& Deci, 2005). Nii näiteks on kirjeldatud ettevõtlusega alustamise motiive, toetudes nn tõmbe- ja tõuketeooriale, mida on alternatiivselt nimetatud ka võimalus- ja vajaduspõhiseks ettevõtluseks (Bosma \& Levie, 2009; Hessels, van Gelderen, \& Thurik, 2008). See tähendab, et ettevõtlustegevuse algatamise motiiv võib olla tingitud nii indiviidi sisemisest huvist ja tahtest ehk tõmbeteguritest (nt iseseisvus, heaolu, tunnustus) kui ka välistest mõjuritest ehk tõuketeguritest (nt töötuks jäämine, väike sissetulek töökohal), kuid sageli võivad otsuseid mõjutada mõlemad, nii tõmbe- kui ka tõuketegurid (Elfving, 2008). Uuringud on näidanud ka seda, et tõmbeteguritest ehk võimalustest mõjutatud ettevõtted on edukamad ning väliste tõukejõudude mõjutatud vajaduspõhine ettevõtlus ei tarvitse olla jätkusuutlik (Gilad \& Levine, 1986; Grilo \& Thurik, 2008; Thurik, Carree, van Stel, \& Audretsch, 2008). Et suurendada teadlike ja mõtestatud valikute tõenäosust, on ettevõtlushariduse kontekstis tähtis uurida erinevaid motiive ettevõtlusega alustamisel ning teadvustada nende võimalikku mõju ettevõtte edasisele käekäigule.

Ettevõtluse valdkonnas populaarsetel motivatsiooniga seotud käsitlustel on sarnaseid jooni autonoomse ja kontrollitud motivatsiooni eristusega isemääramisteooria (self-determination theory) raamistikus, kus rõhutatakse eri tegevuste mõtestatuse ning väärtustamise aspekti (Ryan \& Deci, 2000, 2017). Nimelt eristavad Ryan ja Deci $(2000,2017)$ motivatsiooni, mis rajaneb kas autonoomsetel põhjustel (nt huvi valdkonna ja ettevõtluse vastu, ettevõtlusega tegutsemise põhjuste ja vajalikkuse teadvustamine) või kontrollitud põhjustel (nt ühiskonna surve, vajadus jätkata tegevust pereettevõttes, süütunne enda pere majandusliku seisu pärast). Need motiivid võivad ettevõtlusega tegelemise jooksul ka muutuda. Näiteks võib ettevõtlusega alustamise kavatsus olla ajendatud soovist teistest rohkem teenida, kuid ärivõimaluse ärakasutamisel 
võib see motiiv ajapikku muutuda isiklikult väärtuslikumaks ning väljenduda näiteks soovis panna enda erialaseid võimeid pidevalt proovile. Samuti võivad õppijad tulla ettevõtlusainesse sooviga koguda ainepunkte, kuid õppejõu toel enda tegevust mõtestades võivad nad jõuda ettevõtluse eri aspektide väärtustamiseni. Lisaks on leitud, et need, kes on eri tegevuste suhtes autonoomselt motiveeritud, on valmis panustama rohkem aega ja ressursse ehk nad on tegevusse tugevamalt kaasatud ning suudavad seejuures keerukaid olukordi paremini lahendada, omandada efektiivsemalt uusi teadmisi ning olla ka tagasilöökide suhtes vähem tundlikud (Eseryel, Law, Ifenthaler, Ge, \& Miller, 2014; Reeve, 2009; Ryan \& Deci 2000, 2017). Kuna isemääramisteooria raamistikul põhinevaid uuringuid on ka haridusvaldkonnas palju tehtud, võimaldab kirjeldatud rõhuasetus paremini selgitada võimalusi, kuidas ettevõtlushariduses saaks toetada autonoomse motivatsiooni esilekerkimist (vt ülevaade Ryan \& Deci, 2017). Just autonoomse motivatsiooni teemadele suurema tähelepanu pööramine võimaldab ettevõtlusõppes täiendada võimalus- ja vajaduspõhise ettevõtluse motiivide käsitlust, suunates õppijaid enda tegevusi sügavamalt mõtestama ning luues seeläbi eeldused edasiseks paremaks hakkamasaamiseks.

Peale motivatsiooni mõjutavad ettevõtluskogemust ja selle kulgu ka muud tegurid. Siinses töös on võetud fookusse sellised ettevõtluses olulised pädevused nagu enesejuhtimine, algatusvõime ning loovus. Ühe põhitegurina jätkusuutlikus ettevõtluses nähakse ettevõtja enesejuhtimisoskust (Snyder, Manz, \& Laforge, 1983), mis võimaldab toime tulla emotsioonidega ettevõtlusprotsessi eri etappidel (Cardon, Foo, Shepherd, \& Wiklund, 2012). Ettevõtlusega alustamisel ja selle arengu tagamisel saab tihti määravaks ka tegevus(t)e algatamine, mille korral tuleb tegutseda sündmusi ennetavalt ning ületada eesmärkide täitmisel ette tulevaid raskusi sihikindlalt (Frese, Fay, Hilburger, Leng, \& Tag, 1997). Niisamuti on ettevõtluse ja sellega alustamisega mitmeti seostatud loovust, mis võimaldab luua uuenduslikke lahendusi ja näha uudseid seoseid juba olemasolevate võimaluste vahel (Ward, 2004). Õppijate ettevõtluspädevuse arengu paremaks toetamiseks ettevõtlushariduse kaudu on vaja mõista eelkirjeldatud pädevuste vahelisi seoseid.

Töö eesmärk on uurida kutse- ja kõrgkoolides õppijate seotust ettevõtlusega, ettevõtlusega alustamise motiive ning sellega seotult õppijate hinnangut enda enesejuhtimisoskustele, algatusvõimele ja loovusele. Täpsemalt soovitakse välja selgitada, mis põhjustel on kutse- ja kõrgkoolides õppijad juba ettevõtluse kasuks otsustanud (tegutsemismotiivid) ning kuidas need põhjused sobituvad autonoomse ja kontrollitud motivatsiooni käsitlusse. Lisaks kirjeldatakse artiklis, mille poolest erinevad autonoomse motivatsiooni toel ettevõtlusega alustanud õppijad teiste ettevõtluses oluliste pädevuste (enesejuhtimise, algatusvõime ja loovuse) võrdluses nendest õppijatest, kes on ettevõtlusega alustanud 
kontrollitud motivatsiooni toel või ei ole üldse ettevõtlusega tegelenud. Selline lähtekoht võimaldab rõhutada vajadust pöörata ettevõtlusõppes autonoomse motivatsiooni kujunemisele süsteemsemalt tähelepanu. Uurimuse tulemused annavad väärtuslikku mõtteainet ettevõtluse õpetajatele ja õppejõududele, võimaldades neil õppijate pädevusi óppetöö kaudu senisest veelgi teadlikumalt toetada. Samuti pakuvad tulemused ettevõtlushariduse uurijatele alternatiivset võimalust käsitleda motivatsiooniteemasid isemääramisteooria raamistikus.

\section{Teoreetiline raamistik}

Järgnevalt antakse ülevaade autonoomse ja kontrollitud motivatsiooni olemusest, sidudes käsitluse haridus- ja ettevõtlusvaldkonna uurimustega. Samuti kirjeldatakse selles peatükis enesejuhtimise, algatusvõime ja loovuse rolli ettevõtlusega tegelemisel ning seostatakse käsitletavad teemad ettevõtlushariduse võimalustega.

\section{Autonoomne motivatsioon ettevõtluses ja ettevõtlusõppes}

Autonoomse motivatsiooni teemasid aitab mõtestada isemääramisteooria, kus kirjeldatakse eri motivatsioonitüüpide rolli käitumise dünaamikas ja kvaliteedis ning indiviidi tegutsemise seotust keskkonnaga (vt täpsemalt Ryan \& Deci, 2000, 2017). Isemääramisteooria on terviklik raamistik, mis on kogunud populaarsust eri valdkondades, sh haridusvaldkonnas, kus sel on selge praktiline väärtus. Isemääramisteooria tundmine võimaldab ka ettevõtlusõppes mõista õpetaja/õppejõu võimalusi luua keskkond, mis toetab autonoomse motivatsiooni arengut mitmesuguste ettevõtlusega seotud tegevuste korral.

Isemääramisteooria järgi ei erine motivatsioon mitte ainult intensiivsuse (tugevuse) poolest, vaid erinevad on ka motivatsiooni aluseks olevad tegurid ehk motiivid (tegutsemise põhjused) ning nendest tulenev mõju käitumisele, nt tegutseja püsivus, toimetulek tagasilöökidega, heaolu, enesetunne. Autonoomne motivatsioon on motivatsioonitüüp, mille puhul on tegevus tegutseja enda perspektiivist lähtudes mõtestatud ja väärtustatud ning vastab sellele, mida ta peab enda jaoks oluliseks ja/või huvitavaks (Ryan \& Deci, 2000, 2017). Üks autonoomse motivatsiooni osa on sisemine motivatsioon, mida on ettevõtlusega alustamise ja jätkamise põhjusena sageli rõhutatud tõmbeteooria kaudu (vt Bosma \& Levie, 2009; Hessels et al., 2008). Motivatsioonikontiinumi teises otsas on kontrollitud motivatsioon, mille korral tegutsetakse eri laadi surve, nt välise motivatsiooni allikate, aga ka süütunde mõjul ning tegevus ei ole tegutseja enda perspektiivist vaadatuna mõtestatud. Sellest aspektist on ettevõtluse kontekstis uuritud tasu saamist kui motiivi ning leitud, et ettevõtja 
ja/või töötaja heaolu on suurem, kui ta saab seesmiselt väärtustatud tasu, nt tehtud pingutusega seoses, pere heaolu suurendamiseks, seevastu väiksema heaoluga seostuvad pigem välised tasu saamise motiivid, nt soov teistest rohkem teenida, soov teenida rohkem, et näida edukas (vt Landry et al., 2016).

Autonoomne motivatsioon aitab paljude tegevuste ebahuvitavamaid ja keerulisemaid töölõike ilma välise kontrollita lõpule viia, olles seetõttu väga oluline ettevõtluspädevust mõjutav tegur (näiteid töömotivatsiooni kohta vt Gagné \& Deci, 2005). Inimesed, sh ettevõtjad ja töötajad, kes on autonoomselt motiveeritud, on oma eesmärkide saavutamisel püsivamad ning ei vaja tingimata väliseid motivaatoreid ega ka seda, et tegevus ise oleks igal hetkel nauditav (Ryan \& Deci, 2000, 2017). Samuti võib autonoomne motivatsioon olla teiste sarnaste motiivide realiseerimise eeldus. Seega on autonoomse motivatsiooni käsitluse sidumine ettevõtlusvaldkonna tegevustega hea võimalus uurida eri tegurite omavahelisi seoseid ning kirjeldada neid ettevõtlushariduse kontekstis.

Et mõista võimalusi, kuidas toetada autonoomse motivatsiooni esilekerkimist ettevõtlusõppes, on tähtis kirjeldada teist isemääramisteooria olulist osa. Ryan ja Deci $(2000,2017)$ on rõhutanud, et autonoomse motivatsiooni esilekerkimist, sh liikumist kontrollitud motivatsiooni juurest autonoomse motivatsiooni poole, mõjutab suuresti indiviidi (nt õpilase) psühholoogiliste vajaduste rahuldatus keskkonnas. See tähendab, et kui ettevõtlusõppes pööratakse tähelepanu baasvajadusi toetava keskkonna kujundamisele, luuakse sellega hea alus autonoomse motivatsiooni tekkele kõigepealt ettevõtlusõppes (tähtis ei ole mitte lihtsalt aine läbimine, vaid ka selle sisulise väärtuse tajumine) ning eraldi käsitledes ettevõtluses, kus püütakse mõtestada, miks soovitakse ettevõtlusega alustada jne. Ka teoreetilistes käsitlustes rõhutatakse, et tähelepanu tuleks pöörata kolmele psühholoogilisele põhivajadusele: seotusvajadusele, mille korral tunnetatakse teistega sidet ja enda olulisust, kompetentsusvajadusele, mille korral tunnetatakse enda oskuste piisavust eri tegevuste tarbeks, ning autonoomiavajadusele, mille korral tunnetatakse võimalusi teha ise otsuseid tegevuste ja mõtete tasandil (Ryan \& Deci, 2000, 2017). Eeltoodut arvestades on ettevõtlusõppes tähtis, et õppijad väärtustaksid enda mõtteid ettevõtlusalaste teemade käsitlemisel ning nad usuksid oma võimekusse saada ühe või teise õppeülesandega hakkama. Seejuures tuleks tähelepanu pöörata sellele, et antav ülesanne nõuaks neilt piisavat pingutust ning neil oleks võimalik olla tegevuste ja mõtlemise tasandil piisavalt paindlik ja teha ise otsuseid. Kui ettevõtlusõppes pakutakse võimalusi arutleda ettevõtlusega alustamise motiivide üle ning tuuakse näiteid motivatsiooni seostest ettevõtja toimetulekuga, võib see toetada autonoomse motivatsiooni kujunemist (Ryan \& Deci, 2000, 2017).

Ettevõtlusega (ettevõtluskeskkonnaga) seoses on palju uuritud autonoomiavajaduse rahuldatust ning selle mõju ettevõtjale. Autonoomiat on ettevõtlus- 
alases kirjanduses sageli käsitletud kui ettevõtja õigust otsustada, mis tööd ta teeb ning millal ja kuidas ta seda teeb (van Gelderen, 2016). Uurimustes on leitud, et subjektiivne autonoomiatunne avaldab töökeskkonnas ettevõtlusele suurt mõju, nt võib vähene autonoomiatunne suunata mõtlema ettevõtluse peale ehk olla tõuketegur, samuti peetakse ettevõtluses autonoomiat esmaseks rahuloluallikaks (van Gelderen, 2010). Seega on inimesed, kelle autonoomset motivatsiooni on ettevõtlusõppes püsivalt toetatud, ettevõtlusega tegelemiseks paremini ette valmistatud, kuna ettevõtlus sisaldab peale huvipakkuvate tegevuste ka enesedistsipliini nõudvaid ülesandeid, mida suudavad autonoomselt motiveeritud inimesed järjekindlamalt täita. Autonoomsele motivatsioonile lisaks tuleb arvestada teisi ettevõtluses olulisi pädevusi, nt enesejuhtimist, algatusvõimet ja loovust.

\section{Enesejuhtimine, algatusvõime ja loovus kui autonoomse motivatsiooniga seotud olulised pädevused}

Ettevõtlusega tegelemiseks vajalikke pädevusi on püüdnud kirjeldada mitmed uurijad (nt Baggen et al., 2017; Baum \& Locke, 2004). Rõhu asetamist eri pädevustele mõjutab märkimisväärselt nende tegevuste piiritlemine, mis panevad ettevõtja proovile ettevõtlusprotsessi eri etappidel. Tähtsal kohal ettevõtlusprotsessis on tegevuste algatamine, ideede pakkumine ilma välise surveta, toimetulek ootamatuste ja pingeliste olukordadega, otsuste iseseisev vastuvõtmine jm. Eelnevale tuginedes saab enesejuhtimist, algatusvõimet ja loovust pidada pädevusteks, mis annavad hea lähtekoha paremaks toimetulekuks ettevõtluses (Baron \& Markman, 2003; Glaub, Frese, Fischer, \& Hoppe, 2014; Ucbasaran, Westhead, \& Wright, 2008). Nendele pädevustele keskendutakse ka siinses artiklis.

Enesejuhtimisoskus on ettevõtluse kontekstis oluline igal ettevõtlusega tegelemise etapil, kuid see mõjutab ettevõtjat rohkem just nendes olukordades, mis panevad proovile psühholoogilise (sh emotsionaalse) heaolu. Enesejuhtimine, mis sisaldab oskust märgata enda tegevust kõrvalt, tulla efektiivselt toime mitmesuguste emotsioonidega, uskuda võimete muudetavusse ning ka enda võimesse tulla kõige sellega toime, on seetõttu väga vajalik pädevus (Neck, Neck, Manz, \& Godwin, 1999). Enesejuhtimisoskus mõjutab ka ettevõtja püsivust ning seeläbi ettevõtte võimalusi pidevaks kasvuks. Ettevõtlusõppe kontekstis on enesejuhtimise teemad samuti tähtsad, sest uurimused on näidanud, et enesejuhtimisoskust saab sobiva sekkumise korral efektiivselt arendada, parandades seeläbi ettevõtjate üldist heaolu ja hinnangut enda paindlikkusele saada eri olukordades hakkama (Shepherd \& Krueger, 2002). 
Enesejuhtimisoskus on seotud algatusvõimega, mida võib samuti pidada oluliseks pädevuseks, aga ka teiste ettevõtluse alapädevustega. Näiteks on leitud, et algatusvõimeline inimene on innovaatiline ning püüdleb kindlameelselt eesmärkide poole (Crant, 2000). Töökontekstis on suurem algatusvõime seotud organisatsioonile pühendumise ja töösooritusega ning enam algatusvõimelisi inimesi tähendab organisatsiooni jaoks paremat kohanemisvõimet ja sooritust, iseäranis muutuste ja uuenduste perioodil (vt Glaub et al., 2014). Seega mõjutab individuaalne algatusvõime suuresti seda, kas indiviidist (nt õppijast) saab ettevõtja või mitte (Reuel Johnmark, Munene, \& Balunywa, 2016).

Ühe tegurina, mis võimaldab ettevõtluses toime tulla, on kirjeldatud loovust. Ettevõtluse kontekstis on loovust seotud ettevõtja edukusega mitmeti, nt võimalusena lahendada edukamalt erinevaid probleeme, kasutades sealjuures lahenduste leidmiseks analoogiat ning kandes teadmisi või oskusi ühest valdkonnast teise (Ward, 2004). Kuigi loovust on peetud püsivaks omaduseks, on eri uurimustes leitud, et seda on võimalik kindlal viisil arendada. Nimelt saab loovust käsitleda kui oskust kombineerida (mentaalseid) elemente nii, et tekkival tervikul on uudsed ja kasulikud omadused, samuti nähakse seda oskusena leida seoseid ja sarnasusi ning genereerida lühikese ajaga ideid mingi probleemi lahendamiseks (Diamond \& Lee, 2011; Friedenberg \& Silverman, 2012). Kirjeldatud määratluse järgi toetub loovus suuresti täidesaatvatele funktsioonidele (Diamond, 2013) ning mitmekesistele ja sügavatele valdkonnateadmistele, olles seejuures seotud paljude teiste ettevõtluses oluliste pädevustega, nt probleemilahendusoskusega.

Eelkirjeldatud tegureid on peetud ettevõtluses toimetulekul tähtsaks, kuid neid ei ole otseselt seostatud autonoomse motivatsiooniga. Ometi võib eeldada, et seosed on olemas. Selline eeldus põhineb uurimustel teistest valdkondadest (töö, karjäär, õppimine, sport), kus näiteks otsuste iseseisev vastuvõtmine, tegevuste algatamine, ideede pakkumine ilma välise surveta ja muud sedalaadi tegevused on seotud autonoomse motivatsiooniga (täpsemat ülevaadet vt Ryan \& Deci, 2017). Lisaks on leitud, et autonoomne motivatsioon on seotud oskusega lahendada keerukamaid probleeme, olla tegutsedes rohkem pühendunud ja kaasatud ning tagasilöökide suhtes vähem tundlik (Eseryel et al., 2014; Reeve, 2009; Ryan \& Deci, 2000). Õppetegevusega seoses on aga ilmnenud, et autonoomsemalt motiveeritud õppijad on õppetöös aktiivsemad ning oskavad paremini oma vigu sisuliselt analüüsida (Vansteenkiste, Simons, Lens, Soenens, \& Matos, 2005). DeShon ja Gillespie (2005) on enda uurimuses samuti leidnud, et ettevõtlusega alustamisel võib motivatsioon mõjutada potentsiaalse ettevõtja algatusvõimet, st võimaluste märkamist ja kasutamist ning vastuvõtlikkust uutele ideedele. 


\section{Uurimuse eesmärk ja uurimisküsimused}

Et mõista autonoomse motivatsiooni rolli ettevõtlusega tegelemisel ning võimalusi toetada autonoomse motivatsiooni teket ettevõtlusõppes, on oluline kirjeldada ettevõtlusega alustamise motiive, lähtudes autonoomse ja kontrollitud motivatsiooni käsitlusest, ning seostada neid teiste ettevõtluses oluliste pädevustega. Seetõttu on uurimuse eesmärk kirjeldada kutse- ja kõrgkoolis õppijate motiive seotuna nende ettevõtluskogemusega. Täpsemalt soovitakse uurida, mis põhjustel on õppijad ettevõtlusega alustanud ning kuidas need põhjused sobituvad autonoomse ja kontrollitud motivatsiooni käsitlusse. Uurimuses eeldatakse, et õppijad nimetavad ettevõtlusega alustamise põhjustena sagedamini tasu teenimist ja isiklikku huvi, mida saab siduda autonoomse ja kontrollitud motivatsiooni kontiinumiga (Elfving, 2008; García-Rodríguez, Gil-Soto, Ruiz-Rosa, \& Sene, 2015).

Teine uurimuse eesmärk on kirjeldada muid autonoomse ja kontrollitud motivatsiooniga seotud olulisi ettevõtluspädevusi: enesejuhtimist, algatusvõimet ja loovust. Täpsemalt soovitakse uurida, kas ja kuidas erinevad autonoomse ja kontrollitud motivatsiooni toel ettevõtlusega alustanud óppijad ettevõtluskogemuseta õppijatest, võttes arvesse nende hinnanguid enesejuhtimise, algatusvõime ja loovuse kohta. Uurimuses eeldatakse, et õppijad, keda kannustasid ettevõtlusega alustama autonoomse motivatsiooniga seotud põhjused, hindavad enda enesejuhtimisoskust, algatusvõimet ja loovust kõrgemalt võrreldes õppijatega, kes on olnud ettevõtlusega seotud kontrollitud motivatsiooni kaudu või ei ole ettevõtlusega üldse kokku puutunud (DeShon \& Gillespie, 2005; Ryan \& Deci, 2017). Järgnevalt kirjeldatakse uurimuses püstitatud eesmärke silmas pidades kutse- ja kõrgkoolides õppijate uuringu tulemusi ning käsitletakse nende seoseid varasemate uurimustega.

\section{Meetod}

\section{Osalejad ja protseduur}

Uuring on tehtud Haridus- ja Teadusministeeriumi ettevõtlusõppe programmi „Ettevõtlikkuse ja ettevõtlusõppe süsteemne arendamine kõigil haridustasemetel“ („Edu ja tegu“) raames. Andmeid koguti 2016. ja 2017. aastal Eesti kutse- ja kõrgkoolides nii interneti- kui ka paberküsimustikuga ( ca $5 \%$ oli paberversiooni kujul). Õppijatele edastati ainetundides küsimustiku link ja neil paluti küsimustik täita kas kodutööna või anti selleks aega ainetundides.

Arvestuste kohaselt oli üldkogum umbes 1200 õppijat. Küsimustikule vastajaid oli kokku 497 vanuses $16-64$ eluaastat $(M=22,47, S D=4,80)$. Kutsekoolide 
õpilasi oli 28\%, rakenduskõrgkoolide üliõpilasi 6\%, bakalaureusetaseme üliõpilasi $54 \%$ ja magistritaseme üliõpilasi $11 \%$ (1\% jättis vastamata).

\section{Hindamisvahendid}

\section{Motivatsioon}

Varasemates uurimustes on autonoomset ja kontrollitud motivatsiooni hinnatud eri meetoditel, kuid valdav on siiski valikvastustega väidete kasutamine (nt Black \& Deci, 2000; Gagné et al., 2010). Siinses uurimuses otsustati kasutada meetodit, kus õppijatel lastakse teha valik eri vastusevariantide seast. Autonoomse ja kontrollitud motivatsiooni küsimuste katsetamiseks ning parimate vastusevariantide leidmiseks tehti kõigepealt prooviuuring, milles osales 92 inimest (kellest 47,3\% oli olnud ettevõtlusega seotud), kes vastasid küsimustele vabavastustega. Vabavastuste alusel moodustati vastusevariandid, mida kasutati uuringus. Esmalt küsiti vastajatelt, kas nad on praegu või on varem olnud seotud ettevõtlusega. Need, kes vastasid küsimusele jaatavalt, said valida, mis ettevõtlusvormidega on nad tegelenud (äritegevus, vabatahtlik tegevus, mittetulundusühenduste tegevus ja õppetööga seotud tegevus) ning mis põhjustel on nad ettevõtlusega alustanud. Põhjendused olid valikutena ette antud. Vastajad said valida mitu põhjendust ja lisaks kirjutada vabavastuse.

Toetudes autonoomse ja kontrollitud motivatsiooni käsitlusele (isemääramisteooria, vt Ryan \& Deci, 2017), jaotati ettevõtlusega tegelenud vastajate põhjendused autonoomset motivatsiooni iseloomustavateks põhjendusteks (nt „Pakkus huvi, põnevust“, „,Mul oli idee ja soovisin seda täide viia“, „Nägin ühiskonnas probleeme, mida tahan ja suudan lahendada“) ja kontrollitud motivatsiooni iseloomustavateks põhjendusteks (nt „Kohustuslik, et saada õppeaine koolis läbitud“, „Sest ühiskonnas tunnustatakse ettevõtjaid rohkem“, „Soov teenida tulu"). Vastuste järgi jagunesid vastajad kolme rühma: autonoomseteks vastajateks (autonoomseid valikuid rohkem kui kontrollituid), kontrollitud vastajateks (kontrollitud valikuid rohkem kui autonoomseid) ja segarühmaks (autonoomseid ja kontrollitud valikuid võrdselt). Rühmadevaheliste erinevuste hindamisel lisati analüüsi ka neljas rühm - vastajad, kes ei olnud ettevõtlusega varem tegelenud.

\section{Enesejuhtimine}

Enesejuhtimist hinnati küsimustikuga, mis on koostatud Zhou ja Ee (2012) sotsiaal-emotsionaalse kompetentsuse küsimustiku põhjal. Originaalküsimustik koosneb neljast alaskaalast (enesejuhtimine, sotsiaalne teadlikkus, suhete juhtimine, vastutustundlik otsustamine) ja sisaldab kokku 17 väidet. 
Uuringus kasutati enesejuhtimise alaskaalat, milles oli kolm väidet (nt „Ma suudan oma tundeid juhtida, kui midagi läheb halvasti"). Vastajatel paluti hinnata väidetega nõustumist/mittenõustumist viiepallisel Likerti skaalal.

\section{Algatusvõime}

Algatusvõimet hinnati küsimustikuga, mis on koostatud Frese ja tema kolleegide (1997) tööle tuginedes. Eestikeelsele versioonile on artikli autorid lisanud väiteid, samuti on kohandatud originaalväiteid, et laiendada esialgset kitsamat ettevõtluse algatamise alapädevuse kirjeldust ning käsitleda algatusvõime alapädevust ka nende vastajate korral, kellel ettevõtluskogemus puudub. Küsimustik koosneb kaheksast väitest (nt „Võtan initsiatiivi koheselt ka siis, kui teised seda ei näita"). Vastajatel paluti hinnata väidetega nõustumist/mittenõustumist viiepallisel Likerti skaalal.

\section{Loovus}

Loovust hinnati küsimustikuga, mis tugineb Karwowski $(2013,2014)$ töödele. Originaalküsimustik sisaldab kolme alaskaalat (loovuse, juurdekasvuja jäävususkumused loovuse kohta) ja kokku 16 väidet. Praeguses uuringus kasutatakse loovuse alaskaalat, milles on kuus väidet (nt „Olen kindel, et saan hakkama probleemidega, mis nõuavad loovaid lahendusi“). Vastajatel paluti hinnata väidetega nõustumist/mittenõustumist viiepallisel Likerti skaalal.

\section{Andmeanalüüsi metoodika}

Andmeid analüüsiti programmidega IBM SPSS Statistics 24 ja Mplus 7.3 (Muthén \& Muthén, 1998-2015). Küsimustiku struktuuri kontrollimiseks kasutati konfirmatiivset faktoranalüüsi. Mudeli headust kontrolliti hii-ruudu, CFI (comperative fit index), TLI (Tucker-Lewis index) ja RMSEA (root mean square error of approximation) näitajatega. Mudeli näitajad hinnati sobivaks, kui CFI ja TLI väärtus olid suuremad kui 0,90 ning RMSEA oli väiksem kui 0,08 (vt Hooper, Coughlan, \& Mullen, 2008). Et hinnata rühmadevahelisi erinevusi enesejuhtimises, algatusvõimes ja loovuses, kasutati dispersioonanalüüsi (ANOVA) ja Bonferroni post hoc-testi. Tulemusi hinnati olulisusnivool $\alpha=0,05$. 


\section{Tulemused}

\section{Ettevõtlusega alustamise motiivid}

Esmalt küsiti vastajatelt, kas nad on (olnud) ettevõtlusega mingil moel seotud. $45,5 \%$ õppijatest vastas küsimusele jaatavalt, pidades sealjuures silmas äritegevust, mittetulundustegevust, vabatahtlikku tegevust ning ka seotust õppetööga (nt ettevõtlusainetes või õpilasfirma programmis osalemine). Üksnes õppetöös ettevõtlusega tegelenud vastajaid oli 20,7\% kõigist ettevõtlusega tegelenud vastajatest, sama palju oli ka ainult äritegevusega tegelenud vastajaid. $13,8 \%$ vastajatest oli seotud ainult vabatahtliku tegevusega ning $1,1 \%$ vaid mittetulundusühendustega. Ülejäänud $(43,7 \%)$ olid valinud mitu tegevusviisi. Seejärel küsiti ettevõtlustegevuse alustamisega seotud põhjendusi, mida võis olla mitu. Joonisel 1 on esitatud ettevõtlusega alustamise põhjenduste jaotumus protsentides.

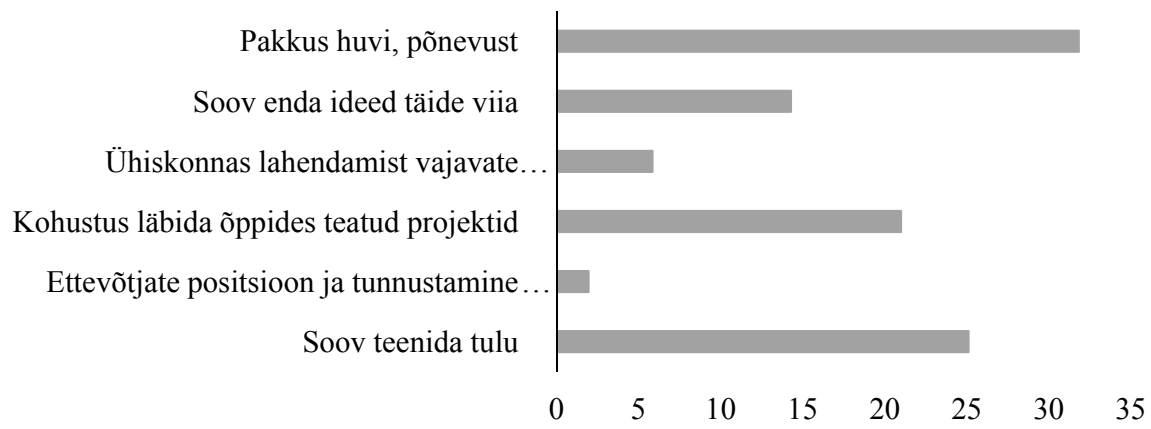

Joonis 1. Ettevõtlusega alustamise põhjenduste protsentjaotus koondvalimi korral

Tulemustest ilmneb, et õppijad teevad nii autonoomsele kui ka kontrollitud motivatsioonile viitavaid valikuid. Rohkem valiti põhjendusteks vastuseid, mis olid seotud huvi ja põnevuse, tulu teenimise ning ka kohustusliku ainevalikuga. Vähem osutusid valituks vastused, mis puudutasid ettevõtjate positsiooni ühiskonnas ning soovi ühiskondlikke probleeme lahendada.

\section{Ettevõtluses oluliste pädevuste erinevused autonoomse ja kontrollitud motivatsiooniga ettevõtluskogemuse korral}

Esmalt kontrolliti enesejuhtimise, algatusvõime ja loovuse küsimustiku struktuuri konfirmatiivse faktoranalüüsiga. Kaiseri-Meyeri-Olkini testi tulemus oli 0,91 ning faktoranalüüsi eeldus väidete omavahelise korreleerumise kohta oli samuti täidetud (kõik väited olid vähemalt ühe teise väitega tugevamas korrelatsioonis kui 0,30 ), seega osutusid andmed faktoranalüüsi jaoks sobivaks. Kõiki 
väiteid hinnati ühes mudelis, milles määrati kolm faktorit (enesejuhtimine, algatusvõime ja loovus) ning iga faktori alla koondati vastava konstrukti kohta käivad väited. Mudeli sobivus andmetega oli hea $\left(\chi^{2}=322,89, d f=109, p<0,01\right.$; $\mathrm{CFI}=0,93$, TLI $=0,91$, RMSEA $=0,06$ ). Standardiseeritud faktorlaadungid on esitatud tabelis 1, seesmise reliaabluse näitajad (Cronbachi $\alpha$ ) tabelis 2 .

Tabel 1. Konfirmatiivse faktoranalüüsi standardiseeritud tulemused

\begin{tabular}{lll}
\hline Küsimustiku väited & \multicolumn{2}{c}{ Faktorlaadungid } \\
\hline Enesejuhtimine 1 & 0,76 & \\
\hline Enesejuhtimine 2 & 0,77 & \\
\hline Enesejuhtimine 3 & 0,57 & \\
\hline Algatusvõime 1 & 0,49 & \\
\hline Algatusvõime 2 & 0,60 & \\
\hline Algatusvõime 3 & 0,71 & \\
\hline Algatusvõime 4 & 0,65 & \\
\hline Algatusvõime 5 & 0,68 & \\
\hline Algatusvõime 6 & 0,38 & \\
\hline Algatusvõime 7 & 0,62 & 0,72 \\
\hline Algatusvõime 8 & 0,67 & 0,64 \\
\hline Loovus 1 & & \\
\hline Loovus 2 & & 0,62 \\
\hline Loovus 3 & & \\
\hline Loovus 4 & & \\
\hline Loovus 5 & & \\
\hline Loovus 6 & & \\
\hline & & \\
\hline
\end{tabular}

Ettevõtluse seisukohalt oluliste pädevuste kirjeldavad statistikud, mida uuringus kasutati, on esitatud tabelis 2. Seoste uurimisel ilmnes, et õppijad, kes hindavad enda loovust kõrgemalt, annavad tõenäoliselt kõrgemaid hinnanguid ka algatusvõime $(r=0,61, p<0,01)$ ja enesejuhtimise väidete kohta $(r=0,34$, $p<0,01)$. Samuti on algatusvõime ja enesejuhtimine omavahel positiivselt seotud $(r=0,38, p<0,01)$.

Tabel 2. Oluliste ettevõtluspädevuste kirjeldavad statistikud 


\begin{tabular}{lccccccc}
\hline & $\begin{array}{c}\text { Vastajate } \\
\text { arv }\end{array}$ & $\begin{array}{c}\text { Väidete } \\
\text { arv }\end{array}$ & Min & Max & Keskmine & SD & $\begin{array}{c}\text { Cronbachi } \\
\boldsymbol{a}\end{array}$ \\
\hline 1. Enesejuhtimine & 496 & 3 & 1,00 & 5,00 & 3,48 & 0,77 & 0,73 \\
\hline 2. Algatusvõime & 497 & 8 & 1,25 & 5,00 & 3,27 & 0,64 & 0,83 \\
\hline 3. Loovus & 497 & 6 & 1,50 & 5,00 & 3,65 & 0,68 & 0,86 \\
\hline
\end{tabular}

Märkus. Mõõdetud nõustumist/mittenõustumist kirjeldaval viiepallisel Likerti skaalal.

Dispersioonanalüüsi tulemused näitavad, et rühmade vahel on erinevused nii loovuses $\left[F(3,493)=7,04, p<0,01, \eta^{2}=0,04\right]$, algatusvõimes $[F(3,493)=16,78$, $\left.p<0,05, \eta^{2}=0,10\right]$ kui ka enesejuhtimises $\left[F(3,492)=4,36, p<0,01, \eta^{2}=0,03\right]$ (vt tabel 3).

Tabel 3. Oluliste ettevõtluspädevuste keskmised tulemused rühmade kaupa

\begin{tabular}{lcccc}
\hline & $\begin{array}{c}\text { Vastajate } \\
\text { arv }\end{array}$ & $\begin{array}{c}\text { Enesejuhtimine } \\
\boldsymbol{M}(S D)\end{array}$ & $\begin{array}{c}\text { Algatusvõime } \\
\boldsymbol{M}(S D)\end{array}$ & $\begin{array}{c}\text { Loovus } \\
\boldsymbol{M}(S D)\end{array}$ \\
\hline Autonoomne & 82 & $3,72(0,80)^{\mathrm{a}}$ & $3,59(0,59)^{\mathrm{a}}$ & $3,85(0,65)^{\mathrm{a}}$ \\
\hline Kontrollitud & 80 & $3,41(0,76)^{\mathrm{a}}$ & $3,34(0,63)^{\mathrm{a}}$ & $3,64(0,63)$ \\
\hline Segarühm & 70 & $3,59(0,70)$ & $3,44(0,46)^{\mathrm{b}}$ & $3,85(0,62)^{\mathrm{b}}$ \\
\hline Ettevõtlusega mitteseotud & 262 & $3,41(0,76)^{\mathrm{a}}$ & $3,11(0,62)^{\mathrm{ab}}$ & $3,54(0,70)^{\mathrm{ab}}$ \\
\hline
\end{tabular}

Märkused. Statistiliselt oluliselt erinevad tulemused on märgitud sama tähega $(p<0,05)$. Mõõdetud nõustumist/mittenõustumist kirjeldaval viiepallisel Likerti skaalal.

Bonferroni post hoc-testi tulemustest (tabel 3) ilmneb, et autonoomse motivatsiooniga rühm ei erine segarühmast (valiti eri tüüpi põhjendusi), kuid statistiliselt olulised keskmiste erinevused avalduvad autonoomse ja kontrollitud motivatsiooniga rühma vahel ning autonoomse motivatsiooniga rühma ja ettevõtlusega mitteseotud vastajate vahel. Autonoomse motivatsiooniga seotud põhjendusi valinud õppijad hindavad ka enda loovust kõrgemalt $(M=3,85$, $S D=0,65)$ kui ettevõtlusega mitteseotud õppijad $(M=3,54, S D=0,70$; $p<0,01)$. Ettevõtlusega mitteseotud õppijad andsid enda loovusele madalamaid hinnanguid ka segarühma õppijatega võrreldes $(M=3,85, S D=0,62$; $p<0,01)$. Autonoomse motivatsiooniga seotud põhjendusi andnud õppijad hindavad enda algatusvõimet $(M=3,59, S D=0,60)$ ja enesejuhtimisoskusi $(M=3,72, S D=0,80)$ kõrgemalt kui kontrollitud motivatsiooniga seotud põhjendusi andnud õppijad (algatusvõime korral $M=3,33, S D=0,64 ; p<0,05$; enesejuhtimise korral $M=3,41, S D=0,76 ; p<0,05)$. Samuti on autonoomse motivatsiooniga õppijate keskmine skoor algatusvõime ja enesejuhtimisoskuste 
korral oluliselt suurem kui ettevõtlusega mitteseotud õppijatel (algatusvõime ja kaasamise korral $M=3,10, S D=0,63$; enesejuhtimise korral $M=3,41$, $S D=0,76 ; p<0,01)$.

\section{Arutelu}

Üks uurimuse eesmärke oli kirjeldada neid kutse- ja kõrgkoolides õppijate motiive ettevõtlusega alustamisel, mis võivad mõjutada ka nende edasist ettevõtlustegevust. Õppijate motiivide kirjeldamisel toetuti isemääramisteooriale (vt Ryan \& Deci, 2017) ning eristati autonoomse ja kontrollitud motivatsiooniga seotud põhjendusi. Uurimistulemused näitavad, et õppijad alustavad ettevõtlusega väga erinevatel motiividel ning paljude õppijate puhul on segunenud nii autonoomsele kui ka kontrollitud motivatsioonile viitavad põhjused. Samuti leiti, et autonoomsele motivatsioonile viitavate põhjuste toel ettevõtlusega alustanud õppijad annavad enda enesejuhtimisoskusele, algatusvõimele ja loovusele kõrgemaid hinnanguid kui kontrollitud motivatsioonile viitavaid põhjendusi toonud õppijad. Kirjeldatud tulemused osutavad võimalusele suunata isemääramisteooriale tuginedes ettevõtlusega alustamise ja ettevõtlusõppes osalemise motiivide teema käsitlemist ettevõtlusõppes senisest veelgi teadlikumalt.

\section{Ettevõtlusega alustamise motiivid}

Uurimuse valimisse kuulunud kutse- ja kõrgkoolides õppijad, kel oli ettevõtluskogemus, jagunesid ettevõtlusega alustamise motivatsiooni poolest võrdselt autonoomsele motivatsioonile, kontrollitud motivatsioonile ning mõlemat tüüpi motivatsioonile viitavatesse rühmadesse. Oodatult valisid autonoomse motivatsiooniga seotud põhjenduste seast õppijad enim enda valdkonnaga seotud huvi ja põnevuse aspekti, mis seostub varasemates uurimustes käsitletud sisemise motivatsiooni ning tõmbeteooria teemadega (vt ka Elfving, 2008). Vähem valiti põhjustena soovi enda ideed teostada ning pakkuda lahendust mõnele ühiskonnas märgatud probleemile. Sarnast motiivi on varasemad uurijad küll täheldanud ettevõtlusega alustamise põhjusena, kuid mitte rõhutanud selle tugevat seotust just ettevõtluse määratlusega (García-Rodríguez et al., 2015; Grilo \& Thurik, 2008). Nimelt on ettevõtluse olulise aspektina nähtud just ühiskonnas väärtuse loomist ning ühe võimalusena saab seda käsitleda ka ühiskonnas märgatud probleemidele lahenduste pakkumisena (FFE-YE, 2012). Tõsiasi, et seda vastusevarianti valiti vähe, võib viidata erinevatele põhjustele. Näiteks ei pruugi õppijad olla enda ettevõtluskogemust samal viisil määratlenud, samuti võib tulemus viidata sellele, et kõnealune motiiv ei ole 
osutunud senise ettevõtluskogemuse puhul määravaks. Toetudes isemääramisteooria mõttekäigule, võib siinkohal luua seoseid ka kompetentsusvajaduse vähese rahuldatusega, mille korral tuntakse, et ühiskonnas levinud probleemidele on liiga raske lahendusi leida, samuti võib ületamatuna tunduda enda algse idee teostamine (Ryan \& Deci, 2000, 2017). Ettevõtlushariduses saaks ideede seostamist ühiskonnas oluliste teemadega senisest veelgi rohkem käsitleda, et soodustada just selliste ettevõtete teket, mis loovad ühiskonna jaoks olulist väärtust.

Õppijate kontrollitud motivatsiooniga seotud põhjendusena osutus oodatult populaarseimaks tulu teenimine, mida on ka varasemate uurimuste järgi peetud ettevõtjate seas üheks peamiseks ettevõtluse alustamisega seotud põhjuseks (vt Elfving, 2008; Zanakis, Renko, \& Bullough, 2012). Kuna uurimuses käsitleti ettevõtlusega seotust ja esimesi kogemusi, mis on saadud eri ainetes tehtavate projektidega, oli populaarne ka valik, mis kirjeldab aine läbimise kohustuslikke eeldusi ettevõttega alustamisel. See kontrollitud motivatsioonile viitav valik võib märkimisväärselt mõjutada tulevaste ettevõtjate suhtumist ettevõtlusesse ning annab märku vajadusest käsitleda autonoomse motivatsiooni teemasid ettevõtlusõppes senisest veelgi süvendatumalt. Kindlasti tuleb silmas pidada, et tehtud valikud vihjavad küll seostele kontrollitud ja autonoomse motivatsiooniga, kuid nii tulu teenimine kui ka aine kohustuslik läbimine võivad endas peita ka mõtestatud valikuid ning ei vihja tingimata vaid kontrollitud motivatsioonile (nt tulu teenimise ja motivatsiooni seosed, vt Landry et al., 2016). Seetõttu tuleks ka ettevõtlusõppe kontekstis motivatsiooni alati täpsemalt uurida. Isemääramisteooria seob autonoomse motivatsiooni teemad ettevõtjat ja ka õppijat ümbritseva keskkonnaga ning pakub võimalust mõtestada õpetamispraktikat, mis toetab kontrollitud motivatsiooni muutumist autonoomseks (Ryan \& Deci, 2000, 2017).

Uurimuses osalevatest õppijatest kolmandik tegi nii autonoomsele kui ka kontrollitud motivatsioonile viitavaid valikuid, seega võibki nt eespool nimetatud tasu teenimise motiiv olla seotud ka isikliku huviga. Varasemad uurimused on näidanud motiivide võimalikku muutumist ajas, nt esialgu tegutsetakse ettevõttes tasu eesmärgil ning hiljem võib tekkida sügavam huvi valdkonna vastu (Carsrud et al., 2009). Seetõttu on just motiivide sidumine isikliku väärtusruumiga (autonoomse motivatsiooni tekke suunamine) ettevõtlusõppe seisukohalt oluline ka juba ettevõtluses tegutsevatele õppijatele, sest motiivid on seotud ettevõtja võimalustega ära kasutada enda kasvupotentsiaali, olles seetõttu jätkusuutliku ettevõtluse eeldus (Zanakis et al., 2012). Autonoomsest ja kontrollitud motivatsioonist tulenevate motiivide uurimine võimaldab paremini mõista ettevõtlusega alustamise motiive ning toetada autonoomse motivatsiooni esilekerkimist ettevõtlusõppes. Vaatlusalune valdkond väärib eri 
meetodite kaudu edasi uurimist, kuid praegune uurimus loob õpetajatele ja õppejõududele hea lähtekoha ettevõtlusõppe tundides eri motiivide üle arutlemiseks, pakkudes mõtteainet, kuidas eri motiivid võivad mõjutada ettevõtte käekäiku.

\section{Ettevõtlusega alustamise motiivide seosed teiste ettevõtluses oluliste pädevustega}

Autonoomsele ja kontrollitud motivatsioonile viitavaid tegutsemise põhjuseid ei ole ettevõtlusõppe kontekstis palju uuritud ning seetõttu oli üks siinse uurimuse eesmärke kirjeldada erinevusi motiivides, lähtudes õppijate enda hinnangust enesejuhtimisoskusele, algatusvõimele ja loovusele, mida on varasemates uurimustes kirjeldatud kui ettevõtluses olulisi pädevusi (nt Amabile, 1996; Frese et al., 1997; van Gelderen \& Jansen, 2006). Uurimuses eeldati, et ettevõtluskogemusega ja just autonoomsest motivatsioonist tulenevatel põhjustel ettevõtlusega alustanud õppijad hindavad teistest kõrgemaks enda enesejuhtimisoskust, algatusvõimet ning loovust. Uurimistulemused kinnitasid püstitatud hüpoteesi, viidates ühtlasi tendentsile, et õppijad, kes on ettevõtlusega alustanud just autonoomsematel motiividel, hindavad kõrgemalt enda teisi pädevusi, sh enesejuhtimisoskust. Varasemad uurimused on samuti näidanud, et autonoomsele motivatsioonile tuginev käitumine on seotud paljude teiste üldist heaolu mõjutavate teguritega, sealjuures on osutatud autonoomse motivatsiooni seostele õppijate parema võimekusega enda tegevusi analüüsida (Ryan \& Deci, 2000, 2017). Autonoomse motivatsiooniga seotud motiividest lähtuvad õppijad analüüsivad sisukamalt ka enda kogemusi, sh ebaõnnestumisi, õppides nendest rohkem (Reeve, 2009; Ryan \& Deci, 2000; Vansteenkiste et al., 2005). Sealjuures tuleks ettevõtlusõppes pöörata tähelepanu nii eri motiivide teadvustamisele kui ka kõigi teiste ettevõtluseks oluliste pädevuste terviklikule arendamisele.

Siinsest uurimusest ilmneb, et need, kes alustavad ettevõtlusega autonoomsest motivatsioonist tulenevatel põhjustel, annavad enda algatusvõimele kõrgemaid hinnanguid kui kontrollitud motivatsioonile tuginevad õppijad ja ettevõtlusega mitteseotud õppijad. See on oluline tulemus, sest varasemad uuringud on näidanud, et ettevõtjate ja töötajate algatusvõime on tugevalt seotud nende edukusega (Tornau \& Frese, 2013). Samuti kinnitab varem tehtud uuring, et ettevõtluskoolitusel on positiivne mõju õppijate algatusvõime arengule (Glaub et al., 2014). Järelikult on nii autonoomse motivatsiooni kui ka algatusvõimega seotud oskuste toetamine ettevõtlusõppes üks olulisi aspekte, mis võimaldab suurendada õppijate võimalusi ettevõtlusega alustamisel ning sellega jätkamisel. 
Nii nagu erinesid enesejuhtimise ja algatusvõimega seotud hinnangud motivatsiooni kohta, ilmnes sarnane tendents ka loovuse puhul. Tuginedes uurimustele teistest valdkondadest, võib eeldada, et autonoomse motivatsiooni toel ettevõtlusega alustanud õppijad oskavad paremini luua eri olukordades uudseid lahendusi (Diamond \& Lee, 2011; Friedenberg \& Silverman, 2012). Kindlasti tuleb tulemuste tõlgendamisel võtta arvesse ka seda, et kirjeldatud seos võib olla mõjutatud teistest loovusega seotud teguritest, nagu parematest kognitiivsetest oskustest ja erialateadmistest. Neid tegureid tuleks järgmistes uurimustes kindlasti arvesse võtta.

Kokkuvõtvalt võib uurimistulemuste toel väita, et ettevõtlusõppes on peale traditsiooniliste ettevõtlusteadmiste (teadmised ettevõtlusprotsessist) oluline tähelepanu pöörata ka teistele ettevõtlusega alustamist mõjutavatele teguritele. Ettevõtlusõppe kontekstis tuleks seetõttu rõhutada õpetajate ja õppejõudude võimalusi aidata õppijatel mõista enda tegutsemise motiive ja arendada sealjuures nende eneseanalüüsioskust. Kõik see on seotud nende üldise parema heaoluga, samuti potentsiaaliga olla ettevõtluses edukas pikema aja vältel ja tulla toime ka keerukate situatsioonidega. Autonoomse motivatsiooni toetamiseks tuleks ettevõtlusõppes pöörata tähelepanu õppijate psühholoogiliste põhivajaduste rahuldatusele, mis on autonoomse motivatsiooni tekkega suuresti seotud (Ryan \& Deci, 2000, 2017). Nii näiteks rõhutatakse vajadust pakkuda õppijale just mõtete tasandil valikuid, suurendamaks temas tunnet, et tema isiklikku panust, pakutavaid lahendusi ja ideid ning diskussiooni nende üle väärtustatakse, et eri lahendused on võimalikud ning et teda ei suunata mõtlema kindlal viisil ega tempos (ibid.). Kuna uurimuse eesmärk on kirjeldada ka autonoomse motivatsiooni uurimise võimalusi ettevõtluse kontekstis, pakuvad tulemused head lähtekohta valdkonna edasiseks uurimiseks, mille korral võetakse arvesse ka teisi mõjutavaid tegureid ning kasutatakse alternatiivseid meetodeid (nt intervjuud motiivide täpsustamiseks, kontekstispetsiifilised ülesanded, mis näitavad loovust, algatusvõimet ja enesejuhtimisoskust).

Kuigi uurimistulemustest ilmnesid erinevad seosed oluliste ettevõtluspädevuste vahel, on uuringul ka mitmeid piiranguid, millega tuleb tulemuste tõlgendamisel arvestada. Näiteks kasutati uuringus enesehinnangulisi skaalasid, mille korral on eelis parema eneseanalüüsivõimega õppijatel. Seetõttu peaks tulemusi kinnitama uuringutega, kus kasutatakse kirjeldatud pädevuste uurimiseks eri tüüpi ülesandeid, samuti avatud küsimusi ja intervjuusid. Ka käsitleti praegusel juhul vaid teatud valikuid, mis puudutasid õppijate motiive ettevõtlusega alustamisel, kuid nende täpsemaks mõistmiseks tuleks õppijate ja ettevõtjatega teha intervjuusid. Lisaks oli küsimustikele vastanute protsent pigem madal (alla 50\%) ning see võib tähendada, et uurimistulemused kirjeldavad motiivide jaotumist vaid konkreetse rühma korral ning ei pruugi 
olla samasugused teistel rühmadel. Valim oli väike ka haridusastmete täpseks võrdlemiseks, see aga võis mõjutada uurimistulemusi, mistõttu tuleks kirjeldatud teemavaldkonda edaspidi uurida laiemal sihtrühmal.

\section{Tänusõnad}

Uurimuse valmimist on toetanud Euroopa Liit Euroopa sotsiaalfondi kaudu, finantseerides Haridus- ja Teadusministeeriumi eestvedamisel elluviidud projekti „Ettevõtlikkuse ja ettevõtlusõppe süsteemne arendamine kõigil haridustasemetel“ („Edu ja tegu“).

\section{Kasutatud kirjandus}

Aijzen, I. (1991). Theory of planned behavior: Some unresolved issues. Organizational Behavior \& Human Decision Processes, 50(2), 179-211. https://doi.org/10.1016/0749-5978(91)90020-T

Amabile, T. M. (1996). Creativity in context: Update to the social psychology of creativity. Boulder: Westview Press.

Baggen, Y., Kampen, J. K., Naia, A., Biemans, H. J. A., Lans, T., \& Mulder, M. (2017). Development and application of the opportunity identification competence assessment test (OICAT) in higher education. Innovations in Education and Teaching International, 1-11. https://doi.org/10.1080/14703297.2017.1348962

Baron, R. A., \& Markman, G. D. (2003). Beyond social capital: The role of entrepreneurs' social competence in their financial success. Journal of Business Venturing, 18(1), 41-60. https://doi.org/10.1016/S0883-9026(00)00069-0

Baum, J. R., \& Locke, E. A. (2004). The relationship of entrepreneurial traits, skill, and motivation to subsequent venture growth. Journal of Applied Psychology, 89(4), 587-598. https://doi.org/10.1037/0021-9010.89.4.587

Black, A. E., \& Deci, E. L. (2000). The effects of instructors' autonomy support and students' autonomous motivation on learning organic chemistry: A self-determination theory perspective. Science Education, 84(6), 740-756. https://doi.org/10.1002/1098-237X(200011)84:6<740::AID-SCE4>3.0.CO;2-3

Bosma, N., \& Levie, J. (2009). Global Entrepreneurship Monitor: 2008 executive report. Babson Park: Global Entrepreneurship Research Consortium.

Cardon, M. S., Foo, M. D., Shepherd, D., \&Wiklund, J. (2012). Exploring the heart: Entrepreneurial emotion is a hot topic. Entrepreneurship Theory and Practice, 36(1), 1-10. https://doi.org/10.1111/j.1540-6520.2011.00501.x

Carsrud, A. L., \& Brännback, M. (2011). Entrepreneurial motivations: What do we still need to know? Journal of Small Business Management, 49(1), 9-26. https://doi.org/10.1111/j.1540-627X.2010.00312.x

Carsrud, A. L., Brännback, M., Elfving, J., \& Brandt, K. (2009). Motivations: The entrepreneurial mind and behavior. In A. L. Carsrud \& M. Brännback (Eds.), Understanding the entrepreneurial mind (pp. 141-165). New York: Springer. https://doi.org/10.1007/978-1-4419-0443-0_7 
Crant, J. M. (2000). Proactive behavior in organizations. Journal of Management, 26(3), 435-462. https://doi.org/10.1177/014920630002600304

DeShon, R. P., \& Gillespie, J. Z. (2005). A motivated action theory account of goal orientation. Journal of Applied Psychology, 90(6), 1096-1127. https://doi.org/10.1037/0021-9010.90.6.1096

Diamond, A. (2013). Executive functions. Annual Review of Psychology, 64, 135-168. https://doi.org/10.1146/annurev-psych-113011-143750

Diamond, A., \& Lee, K. (2011). Interventions shown to aid executive function development in children 4 to 12 years old. Science, 333(6045), 959-964. https://doi.org/10.1126/science.1204529

Elfving, J. (2008). Contextualizing entrepreneurial intentions: A multiple case study on entrepreneurial cognitions and perceptions. Turku: Åbo Akademi förlag.

Eseryel, D., Law, V., Ifenthaler, D., Ge, X., \& Miller, R. (2014). An investigation of the interrelationships between motivation, engagement, and complex problem solving in game-based learning. Educational Technology \& Society, 17(1), 42-53.

FFE-YE (2012). Impact of entrepreneurship education in Denmark - 2011. Odense: The Danish Foundation for Entrepreneurship - Young Enterprise. Retrieved from http://eng.ffe-ye.dk/media/202248/impact_of_entrepreneurship_education_in_ denmark_2011.pdf.

Frese, M., Fay, D., Hilburger, T., Leng, K., \& Tag, A. (1997). The concept of personal initiative: Operationalization, reliability and validity in two German samples. Journal of Organizational and Occupational Psychology, 70(2), 139-161. https://doi.org/10.1111/j.2044-8325.1997.tb00639.x

Friedenberg, J., \& Silverman, G. (2012). Cognitive science: An introduction to the study of mind (2nd ed.). Thousand Oaks, London, New Delhi: Sage.

Gagné, M., \& Deci, E. L. (2005). Self-determination theory and work motivation. Journal of Organizational Behavior, 26(4), 331-362.

https://doi.org/10.1002/job.322

Gagné, M., Forest, J., Gilbert, M. H., Aubé, C., Morin, E., \& Malorni, A. (2010). The motivation at work scale: Validation evidence in two languages. Educational and Psychological Measurement, 70(4), 628-646.

https://doi.org/10.1177/0013164409355698

García-Rodríguez, F. J., Gil-Soto, E., Ruiz-Rosa, I., \& Sene, P. M. (2015). Entrepreneurial intentions in diverse development contexts: A cross-cultural comparison between Senegal and Spain. International Entrepreneurship \& Management Journal, 11(3), 511-527. https://doi.org/10.1007/s11365-013-0291-2

Gilad, B., \& Levine, P. (1986). A behavioral model of entrepreneurial supply. Journal of Small Business Management, 24(4), 45-54.

Glaub, M. E., Frese, M., Fischer, S., \& Hoppe, M. (2014). Increasing personal initiative in small business managers or owners leads to entrepreneurial success: A theory-based controlled randomized field intervention for evidence-based management. Academy of Management Learning and Education, 13(3), 354-378. https://doi.org/10.5465/amle.2013.0234

Grilo, I., \& Thurik, R. (2008). Determinants of entrepreneurial engagement levels in Europe and the US. Industrial and Corporate Change, 17(6), 1113-1145. https://doi.org/10.1093/icc/dtn044 
Hessels, J., van Gelderen, M., \& Thurik, R. (2008). Entrepreneurial aspirations, motivation and their drivers. Small Business Economics, 31(3), 323-339. https://doi.org/10.1007/s11187-008-9134-x

Hooper, D., Coughlan, J., \& Mullen, M. (2008). Structural equation modelling: Guidelines for determining model fit. Electronic Journal of Business Research Methods, 6(1), 53-60.

Karwowski, M. (2014). Creative mindsets: Measurement, correlates, consequences. Psychology of Aesthetics, Creativity, and The Arts, 8(1), 62-70. https://doi.org/10.1037/a0034898

Karwowski, M., Lebuda, I., Wisniewska, E., \& Gralewski, J. (2013). Big five personality traits as the predictors of creative self-efficacy and creative personal identity: Does gender matter? The Journal of Creative Behavior, 47(3), 215-232. https://doi.org/10.1002/jocb.32

Landry, A. T., Kindlein, J., Trépanier, S.-G., Forest, J., Zigarmi, D., Houson, D., \& Brodbeck, F. C. (2016). Why individuals want money is what matters: Using selfdetermination theory to explain the differential relationship between motives for making money and employee psychological health. Motivation and Emotion, 40(2), 226-242. https://doi.org/10.1007/s11031-015-9532-8

Muthén, L. K., \& Muthén, B. O. (1998-2015). Mplus user's guide (6th ed.). Los Angeles: Muthén \& Muthén.

Neck, C. P., Neck, H. M., Manz, C. C., \& Godwin, J. (1999). "I think I can; I think I can": A self-leadership perspective toward enhancing entrepreneur thought patterns, self-efficacy, and performance. Journal of Managerial Psychology, 14(6), 477-501. https://doi.org/10.1108/02683949910287912

Reeve, J. (2009). Why teachers adopt a controlling motivating style toward students and how they can become more autonomy supportive. Educational Psychologist, 44(3), 159-175. https://doi.org/10.1080/00461520903028990

Reuel Johnmark, D., Munene, J. C., \& Balunywa, W. (2016). Robustness of personal initiative in moderating entrepreneurial intentions and actions of disabled students. Cogent Business \& Management, 3(1). https://doi.org/10.1080/23311975.2016.1169575

Ryan, R. M., \& Deci, E. L. (2000). Self-determination theory and the facilitation of intrinsic motivation, social development and well-being. American Psychologist, 55(1), 68-78. https://doi.org/10.1037/0003-066X.55.1.68

Ryan, R. M., \& Deci, E. L. (2017). Self-determination theory: Basic psychological needs in motivation, development, and wellness. New York: Guilford Publications.

Shane, S. (2003). A general theory of entrepreneurship. Cheltenham: Edgar Elgar. https://doi.org/10.4337/9781781007990

Shepherd, D. A., \& Krueger, N. F. (2002). An intentions-based model of entrepreneurial teams' social cognition. Entrepreneurship Theory and Practice, 27(2), 167-185. https://doi.org/10.1111/1540-8520.00005

Snyder, C. A., Manz, C. C., \& Laforge, R. W. (1983). Self-management: A key to entrepreneurial survival? American Journal of Small Business, 8(1), 20-26. https://doi.org/10.1177/104225878300800107 
Zanakis, S. H., Renko, M., \& Bullough, A. (2012). Nascent entrepreneurs and the transition to entrepreneurship: Why do people start new businesses? Journal of Developmental Entrepreneurship, 17(1). https://doi.org/10.1142/S108494671250001X

Zhou, M., \& Ee, J. (2012). Development and validation of the Social Emotional Competence Questionnaire (SECQ). The International Journal of Emotional Education, $4(2), 27-42$.

Thurik, A. R., Carree, M. A., van Stel, A., \& Audretsch, D. B. (2008). Does selfemployment reduce unemployment? Journal of Business Venturing, 23(6), 673686. https://doi.org/10.1016/j.jbusvent.2008.01.007

Tornau, K., \& Frese, M. (2013). Construct clean-up in proactivity research: A metaanalysis on the nomological net of workrelated proactivity concepts and their incremental validities. Applied Psychology: An International Review, 62(1), 44-96. https://doi.org/10.1111/j.1464-0597.2012.00514.x

Ucbasaran, D., Westhead, P., \& Wright, M. (2008). Opportunity identification and pursuit: Does an entrepreneur's human capital matter? Small Business Economics, 30(2), 153-173. https://doi.org/10.1007/s11187-006-9020-3

Van Gelderen, M. (2010). Autonomy as the guiding aim of entrepreneurship education. Education + Training, 52(8/9), 710-721. https://doi.org/10.1108/00400911011089006

Van Gelderen, M. (2016). Entrepreneurial autonomy and its dynamics. Applied Psychology: An International Review, 65(3), 541-567. https://doi.org/10.1111/apps.12066

Van Gelderen, M., \& Jansen, P. (2006). Autonomy as a start-up motive. Journal of Small Business \& Enterprise Development, 13(1), 23-32. https://doi.org/10.1108/14626000610645289

Vansteenkiste, M., Simons, J., Lens, W., Soenens, B., \& Matos, L. (2005). Examining the motivational impact of intrinsic versus extrinsic goal framing and autonomysupportive versus internally controlling communication style on early adolescents' academic achievement. Child Development, 76(2), 483-501. https://doi.org/10.1111/j.1467-8624.2005.00858.x

Ward, T. B. (2004). Cognition, creativity, and entrepreneurship. Journal of Business Venturing, 19(2), 173-188. https://doi.org/10.1016/S0883-9026(03)00005-3 


\title{
Students' autonomous motivation in relation to self-management, initiative and creativity when becoming an entrepreneur
}

\author{
Elina Malleus $^{\mathrm{acl}}$, Urve Venesaar ${ }^{\mathrm{b}}$, Kaja Mädamürk ${ }^{\mathrm{ab}}$, Grete Arro ${ }^{\mathrm{c}}$ \\ ${ }^{a}$ School of Natural Sciences and Health, Tallinn University \\ ${ }^{b}$ School of Business and Governance, Tallinn University of Technology \\ 'School of Educational Sciences, Tallinn University
}

\begin{abstract}
Summary
Motivation has been an important research object of entrepreneurship that helps to understand what drives individuals towards entrepreneurial activities and how different motives of starting entrepreneurship are influencing the company's further development (Aijzen, 1991; Carsrud \& Brännback, 2011; Shane, 2003). Motivation does not only differ in the aspects of strength, but also its quality, offering different opportunities to describe motivation (Carsrud et al., 2009; Gagné \& Deci, 2005). Within the framework of self-determination theory (SDT) that is gaining popularity in various fields, researchers have distinguished between autonomous motivation (e.g. being interested in the field and entrepreneurship, having thought through the reasons and necessity of starting entrepreneurship) or controlled motivation (e.g. pressure from the society, need to continue a family business, guilt about the family's financial situation; Ryan \& Deci, 2000). Researchers have found that people who are autonomously motivated towards different activities are also more engaged and can thereby, for example, solve complicated problems better, acquire new knowledge more effectively and be less sensitive to setbacks (Eseryel et al., 2014; Reeve, 2009; Ryan \& Deci, 2000). Specific motives can change whilst being an entrepreneur and thus, growth of specific motives (e.g. autonomous motivation) can be supported through entrepreneurship education. For example, the intention of starting a company can be induced by the necessity of making a living, but after exploiting a business opportunity, an internal interest may arise.

As exploiting business opportunities is possible only as a result of an active engagement by the entrepreneur, understanding entrepreneurial behaviour and factors affecting it can help to explain how entrepreneurs create new
\end{abstract}

School of Natural Sciences and Health, Tallinn University, Narva mnt 29, 10120 Tallinn, Estonia; elina.malleus@tlu.ee 
organisations. In starting entrepreneurship, there are different factors that are emphasised more in the literature affecting the process. It is important to be resilient in constantly changing (difficult) situations and resilience has been found to be related with having higher self-management skills, creativity and sense of initiative (Frese et al., 1997). In entrepreneurship education, it is important to increase the students' awareness of their behaviour and different factors that may be related to various situations. An outcome of entrepreneurship education can, therefore, be seen as offering possibilities to give sense to entrepreneurship-related thoughts and activities, as well as supporting the emergence of autonomous motivation.

In connection to entrepreneurship, the topics of motivation has been previously emphasised, but the relationship between autonomous motivation and other factors related to entrepreneurial success have been studied less. Thus, the objective of the current study was to assess the causes of deciding to be an entrepreneur, based on continuum of autonomous and controlled motivation, and to study different types of motives in relation to self-management skills, initiative and creativity. More specifically, the reasons why students decided to become or not to become an entrepreneur were studied, using a sample of students from universities and vocational schools throughout Estonia $(N=497$; age 16-64).

The results of the study showed that students had a variety of reasons when starting a business and autonomous and controlled reasons were highlighted. More studies should be carried out with different methods (e.g. interviews) to understand better the variety of students autonomous and controlled motivation, but this study showed that interest and desire to carry out one's ideas are the most popular motives connected to autonomous motivation. Making money and completing projects to get a grade at school were motives described more often by students as controlled motivation. Similar results are found in previous studies, but not explicitly related to autonomous and controlled motivation (Elfing, 2008; Zanakis et al., 2012). Entrepreneurship education can support students by way of being more aware of different reasons that are behind their acts related to entrepreneurship. Prior studies that are based on SDT also describe how autonomous motivation is related to better outcomes in different situations and how the learning environment can support the growth of autonomous motivation being therefore suitable also for entrepreneurship education (Reeve, 2009; Ryan \& Deci, 2000; Vansteenkiste et al., 2005).

Secondly, the goal was to understand if there was a difference in selfmanagement skills, sense of initiative and creativity between students who had started a business with autonomous motivation compared to students that had started a company with controlled motivation or had not started a company 
at all. The results showed that students who had started the business based on autonomous motivation had also rated their self-management skills, initiative and creativity higher. As we used students' own ratings in our study, the overall better self-awareness may have mediated relations between different variables and, therefore, more studies should be done using different methods. However, our study still highlights the importance of paying attention to different aspects in entrepreneurial competence and how supporting students' awareness of their own motives behind making choices can affect their overall entrepreneurial behaviour and success. Therefore, different aspects that are related to entrepreneurship competence should be systematically supported through entrepreneurship education. Paying more attention to supporting growth of autonomous motivation may also be important in entrepreneurship education for entrepreneurs to be more aware of their behaviour and, therefore, be resilient in various situations.

Keywords: entrepreneurship education, autonomous motivation, motives for entrepreneurship, self-management, creativity 